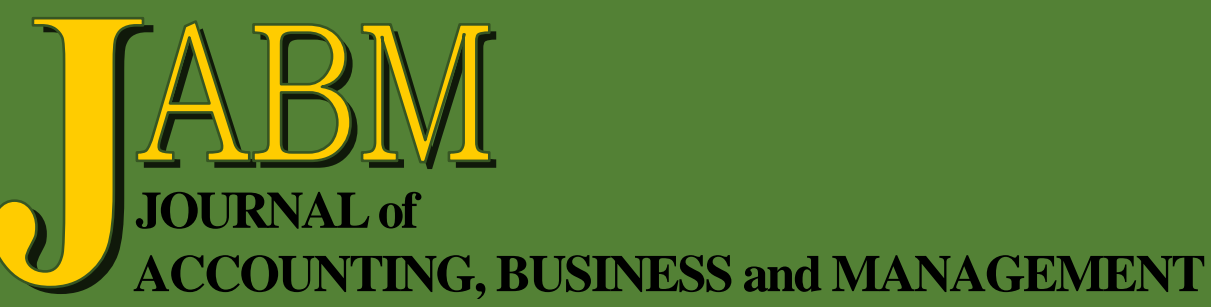

Audit Fee Premium for Industry Specialization: A Developed Country Perspective

Muhammad Shahin Miah

Socio-Demographics Characteristics on Investment Objectives of Individual Investors: Empirical Study in Indonesia

Nevi Danila, Zaiton Ali, Bunyamin and Marlinda D. K.

Dynamic Inflation and Economic Growth Nexus in Bangladesh

Md. Nezum Uddin

Voice of the Customer: Creating Client Centered Cultures in Accounting Firms for Retaining Clients and Increasing Profitability Leisa Gill, Vikkie McCarthy and David Grimmett

Rating the Credit Raters

A. Seetharaman, Nitin Patwa and Shriram Nagarajan 


\title{
Rating the Credit Raters
}

\author{
A. Seetharaman* \\ Nitin Patwat \\ Shriram Nagarajan $\neq$
}

\begin{abstract}
The current research identifies the rating of credit raters by evaluating how credit rating agencies are involved in rating the corporate. It determines the credibility and reliability of their scores based on various variables presenting the credit history and credit worthiness of corporate operating in global perspectives including the United States, UK and India. The paper indicates that there should be some agencies or financial bodies that oversee the processes and procedures of credit raters rating the corporate worldwide. The research explores and norms and practices of the rating of credit raters and determines how the selected variables would be helpful in determining the credibility and authenticity of the credit raters in financial markets. It highlights the implications of the opinions of these credit raters on the performance and future growth of the corporate and predicts what measures should be adopted in rating the credit worthiness of corporate operating in developing countries.

This research indicates how these variables could affect the processes of credit raters and gives a direction to the policymakers and financial experts on the performance and creditworthiness of the financial opinions and ratings of the credit raters.
\end{abstract}

Keywords: credit rating agencies, credit raters, financial markets, ethical practice, financial performance, credit rating process.

\section{INTRODUCTION}

The current research evaluates how to rate the credit raters itself that operate in the global perspectives of rating the corporate on the basis of several criteria. Paper identifies some specific variables and explains whether credit raters (credit rating agencies) adopt all these measures for rating the corporate. It highlights the loopholes in the credit rating processes of credit rating agencies that they have adopted for different corporate around the world (Kisgen \& Strahan, 2010). It explores on what basis these organizations or agencies evaluate the authenticity of the credit rating of the credit raters. In the past, there have been different scandals of the credit raters like Moody's, Standard \& Poor's and Fitch and the paper addresses the credibility of these agencies after carefully evaluating their process of credit ratings (Amato \& Furfine, 2004).

The current research discusses the credibility of the opinions of credit raters on the basis of some well selected variables and how they affect the ratings of the credit raters in making their opinions about corporate. Credit raters offer their services to the

\footnotetext{
* Dean-Academic Affairs. S P Jain School of Global Management Singapore. E-mail: seetha. raman@spjain.org.

† Associate Professor. Director Simulations-Dubai, S P Jain School of Global Management. Block 5, Dubai International Academic City, P O Box 502345, UAE. Phone: +971 45616749.

E-mail : nitin.patwa@spjain.org. Web page: www.spjain.org.

‡Research Scholar. S P Jain School of Global Management, Dubai.
} 
corporate in capital markets to determine their credibility among their potential customers (Ferreira \& Gama, 2007). The study evaluates the sovereignty of the assessment of credit raters on the basis of which they rate corporate around the globe. Three major world players contribute greatly in rating the corporate including the Moody's credit rating, S\&P and Fitch (Hunt, 2008). But the question arise do they rate corporate ethically and morally considering each and every variable which is essential for credit rating purposes (Becker \& Milbourn, 2011). The research also addresses another vital question to determine do these credit raters really think globally and their opinions are trustworthy. The question regarding the credibility of credit raters have become vital after they received harsh criticism following the East Asian Financial crisis (He et al., 2012). Credit raters hold important role about rating the corporate and playing their dominant role in the financial market. The opinions of credit raters also hold important position because they could make considerable influence worldwide about the credibility of the financial institutions and corporate operating their operations worldwide. Their influential role has also increased in the context of new Basel criterion which is used to link capital assets of banks to the corporate and sovereign ratings (Restrepo, 2013).

\subsection{Importance of the Study}

Competition is increasing among organizations operating at the global level and credit raters determine how effectively they are performing and meeting international credit rating standards. If credit raters expand credible information, it would help corporations to improve their financial and credit-related performance (Focardi \& Fabozzi, 2005). But, negative ratings would make huge impact on declining the financial stability of a company offering their financial services in emerging markets. Therefore, study discusses what norms credit raters adopt to consider the ratings for the corporate and whether their credit rating processes involves loopholes in making credit rating decisions regarding the credit repayment performance of the credit rating companies (Haan \& Amtenbrink, 2011).

The role of credit rating agencies is regarded highly credible and authentic in overseeing the credit history of the corporate. These agencies are highly responsible to determine the credit rating of different corporate and their decisions determine the credibility and reliability of companies in front of their customers (Jais et al. 2016). But, if they make negative decisions in rating the corporate, it would cost those companies a lot and despite their good credit performance their credibility damages badly in competitive business environment (He et al., 2012). Indeed, in the course of recent financial crisis, credit raters received huge criticism for not performing their services ethically and for adopting pro-cyclical rating behaviors that would cost the credibility of good credit performers (Louberge \& Schlesinger, 2005). It is reality that credit raters can play influential role while operating in the financial markets and their rating behaviors and methods have their relative importance respectively. But, due to recent criticism on credit rating agencies behavior, the credit raters have also come under strong and close scrutiny. The sovereignty of credit raters has been determined and their performance has also been evaluated in the recent years (Micu et al., 2004).

The curiosity regarding the partiality and unbiased behavior of credit raters have increased due to recent complications regarding their credit rating processes. Some researchers believed that credit raters adopt different standards for rating firms in developing countries and developed countries. Indeed, it has become a critical issue in determining the linkage between the sovereignty of credit raters' decisions and their decisions actually rating the corporate for developing countries, but not for developed 
ones. Regarding the sovereignty of the credit raters, in developing countries sovereignty has been downgraded for giving ratings to the corporate, while upward credit rating decisions are made for corporate in developed countries which indicate discriminatory behavior of credit raters in developing and developed countries. It should be avoided to enhance the credibility of credit raters to be most credible and reliable among corporate world (Ryan, 2012).

\section{REVIEW OF THE LITERATURE}

\subsection{Conflict of Interest}

The credit raters more often give their opinions on the credit worthiness of the companies at the request of institutions themselves. Despite the fact that they now and again direct spontaneous assessments on organizations and offer the appraisals to financial specialists, they are usually paid by the exceptionally same institutions they are rating. Clearly, this framework is associated with serious complications of conflict of interest and should be avoided to enhance the credit worthiness of these agencies (Skreta \& Veldkamp, 2009). The credit raters in global business environment often rate the corporate on the basis of requests received from their management to decide their ratings. The Department of Justice has begun exploring the FICO score organizations for their part in the mortgage-backed securities that collapsed in 2008 (Care et al., 2013).

The current research evaluates that conflict of interest strongly influences the ratings of the credit raters and it is the variables that could impact their rating processes and procedures in rating the corporate. Appropriate policies and procedures to achieve and address conflicts of interest are being put in place. However, these conflicts spread to and not limited to compensation, consulting and advisory services, and personal and ownership conflicts affiliation with issuers. Prohibition of receiving of gifts by rating agencies from those they are rating will increase the agencies objectivity in terms of rating (Goddard et al., 2009).

Specific institutional requests: credit raters often give their opinions on the basis of specific institutional requests from the corporate conducting their business operations globally. It indicates conflict of interest on the part of these credit raters and their opinions decrease their credibility among other corporate that are actually growing and competing all over the world. In the U.S. credit raters hide behind the First Amendment regarding their credit rating processes and procedures. Despite their biased opinions regarding specific institutional requests, credit raters claim that they can never be held accountable for rating corporate on their specific interest (Care et al., 2013).

Biased opinions: after the global financial crisis, it was perceived by the government of EU countries that most of the predictions of the credit raters were biased and based on falsified information. The credit raters were unable to predict about the deepening financial crisis that erupted the world during 2007 and 2008. It enhanced the conflict of interest regarding their opinions for rating the corporate globally (Skreta \& Veldkamp, 2009).

Ineffectiveness to adopt effective rating policies: the conflict of interest also increases and it would affect the ratings of credit raters if they not adopt appropriate policies for procedures in rating the globally operating corporate. The recent financial crisis and their rating policies and principles indicated conflict of interest on the part of credit raters in rating the corporate without having effective rules, regulations and policies laid down by their policy makers (Goddard et al., 2009). 
Quantum fees paid by the corporate: the rating of global raters and the quantum of fee paid by the corporate could also increase conflict of interest in performing their rating operations. If they receive rating fees from the corporate and make their opinion on their specific institutional requests, it would increase the margin of conflict of interest in their rating decisions. The disclosure of information is also important for credit raters and it would affect the performance of globally operating corporate regarding their rating opinions (Ryan, 2012).

Increased competition: Ryan (2012) highlighted that due to increased competition among credit raters, it would transfer highly essential information to the investors by assessing financial performance of the corporate operating in developed countries. The credit raters help the investors and issuers by evaluating the credit worthiness of the corporate in specific industry to help determine the risks of investment and to invest according to changing market conditions (Graham \& Harvey, 2001).

Hypothesis $\mathbf{H}_{1}$ : conflict of interest has significant influence on rating the credit raters in their global operations of rating the corporate.

\subsection{Debt}

Investors also prefer investing in those firms whose bond value is rated positively (Biglaiser \& Derouen, 2007). Credit scores on the bond value of these firms demonstrate higher or lower level of debt and determine the likelihood that the debt would not be reimbursed on time in full. The debt describes the company's ability to make their interest payments on loans but it would make no influential role in the ratings of the credit raters to the global corporate. Debt level of the corporate is important for investors and debtors to make their financial investments in those corporate (McAndrews \& Rochet, 2009). Turvey et al., (2012) evaluated small businesses and associated risks to contingent credit and presented the situation in which firms may face continuous income volatility and face downside risks because their returns on assets were not sufficient to meet their operational and financial needs.

Debt level of the corporate: the debt level of the corporate makes no significant influence on the ratings of the credit raters in the current study in their process of rating globally operating corporate. The debt level of the corporate is directly associated with the financial risks and it could make negative effect on the relationship of debt and ratings of the credit rating agencies. The current research also elaborates that collaborated loans and their risk-based operations can be successfully used to determine the credit worthiness of the globally operating corporate within their specific business environments (Varotto, 2011).

Direction to investors: Kreps et al. (1982) demonstrated that an embedded structured credit product would be helpful to reduce the financial risks. The debt of the corporate gives a direction to the investors and debtors whether to invest or not in global corporations. It would help in achieving desired objectives of the corporate to expand their global operations by getting creditworthiness among major investors.

Credit scores of corporate and bond value: the debt level of the corporate also indicates their credit scores associated with their bond value and if it is positive it would make strong influence on rating the credit raters in conducting their global operations. But, if it is negative it would make negative impact on the ratings of the credit raters. It would be helpful for the corporate to reduce their credit risks associated with their financial market products through scheduling the payouts and linking specific commodities or indices (Goh \& Ederington, 1993). 
Hypothesis $\mathbf{H}_{2}$ : debt level and credit score of the corporate has considerable influence on the rating of credit raters in their global operations of rating corporate.

\subsection{Length of Credit History of the Company}

Good credit history of the corporate is always essential for the company to continue their business operations in a credible manner. It depends on a lot of positive qualities of the company (Che et al., 2014). Companies can develop a good credit history if they continue performing their business operations with patience. Age of credit history is considered to be one of the main fundamental factors that would influence the credit score of a company (Dimson, 1979). It is not something that companies can achieve overnight and always take time in building the credit history of the company. The age of the credit history is certainly important for a business and honestly CRAs should assign a good score if the credit history of the company is impressing (Haan \& Amtenbrink, 2011). Ashbaugh-Skaife e al., (2006) examined how corporate governance of the firms can be important in determining their effects on the rating of credit raters. Credit raters rate those firms higher that how better corporate governance relative to weaker corporate governance firms. They rate negatively to those firms that are associated with takeover defense, timely earnings, board independent and board expertise firms. The authors of this study explored the areas that credit raters prefer to rate firms depending on their CEO $\mathrm{s}$ initiatives to overcompensate their firms to a greater degree on the basis of their comparison with the firms of investment grade ratings. The authors give the explanations why some firms are not rated better in comparison to other firms due to their weaker governance issues (Haan \& Amtenbrink, 2011).

Credit history: good credit history is essential for globally operating corporate, though it's not essential that good credit history would always make good impact on the ratings of corporate determined by global rating agencies. Andrews and Varrasi (2015) observed that through mergers and acquisition, firms can improve their credit history and goodwill for their investors. It also indicates the applicability of share prices as a measure for the value creation that the credit rating agencies assign to some firms (Hand et al., 1992).

Financial background: the researchers also observed changes in the credit rating processes of credit raters by determining the financial background and performance of the firms as an important indicator in determining the credit worthiness of the corporate. The study explored negatively associated abnormal returns for the firms that are associated with downgrade announcements (Chijoriga, 2011). On the other hand, it explored positive insignificant returns for those firms that are associated with abnormal returns to upgrade announcements. The current research also determined significant negative relationship with those firms that have abnormal long-term operating performance for downgrades and less significant for those firms that have less significant effects for their upgrades (Graham \& Harvey, 2001).

Corporate relationship with investors: the relationship of corporate with their investors is regarded as an important indicator for determining the rating processes of the credit raters. The credit worthiness of the corporate is directly associated of their relationship with their financial investors though length of credit history is negatively associated with the ratings of the credit raters (Guimon, 2005). From the mid-1990s, the role of credit rating agencies (CRAs) has been progressively reprimanded. Overseeing several financial crises like the Mexican Tequila Crisis in 1994 to the Asian 
Financial Crisis in 1997-98 and from the European Financial Scandal in 2001 to Parmalat Chapter 11 in 2003, the credit rating agencies have been rebuked for neglecting the cautious speculators of unavoidable corporate or sovereign default. The indignation coordinated at these agencies indicates the level of power they have in financial markets (Fatemi \& Fooladi, 2006).

Hypothesis $\mathbf{H}_{3}$ : length of Credit history of the company has influencing role in rating of credit raters in their global operations of credit ratings.

\subsection{Demonstration of Company's Willingness to Repay Debt}

The demonstration of a company to repay its debt also indicates the sovereign debt which depends largely on the willingness of the company to repay its debt. The sovereignty of debt is considered to be important for global corporate but it makes no considerable influence on the ratings of the credit raters (Poon, 2003). Companies can achieve sovereignty of debt by buying large numbers of assets. If companies enjoy sovereign debt, investors' confidence would also be increased and credibility of the company among their potential buyers will also be increased. Company's ability or willingness to repay its debts can be determined through the solvency and asset liquidity of the company (Kenneth, 2015). Liu and Ferri (2001) determined the credit rating policies of credit rating agencies for the corporate operating at global level like the US, UK and India. The authors evaluated the sovereignty of the decision of credit raters in the global perspectives by comparing their credit rating decisions in countries like the US, UK and India. The authors described the relative contribution of the credit level risks of the firms and sovereign firms in meeting their rating assignments worldwide.

Corporate willingness to repay debt: the corporate willingness determine how corporate are willing to repay their debt to the external debtors. Its contribution in rating the corporate by the credit rating agencies still not so influencial (Fama \& French, 1989). Sovereign risk is also important for globally operating corporate because it would determine the relative importance for each of these factors used in observing and assessing the rating of the corporate.

Sovereignty of debt: the research findings revealed that sovereign risks contribute greatly to determine how credit raters are rating the corporate worldwide, whereas credit risks should be given necessary attention because it can play an important negligible role of assigning these ratings to these firms in developing countries (White, 2010). The firms operating in developing countries were rated by credit raters on the basis of country ceiling effects where private ratings showed upward direction due to their sovereign rating.

Buying large assets: the sovereignty of debt through buying large assets could make some influence on the ratings of the credit raters in the rating the corporate on the basis of their credit sovereignty. It explored that rule of laws and other important indicators could play an important role regarding unsatisfactory rating of the corporate operating in developing countries (Ashcraft et al., 2011).

Hypothesis $\mathbf{H}_{4}$ : demonstration of company's willingness to repay \& sovereignty of debt has a positive impact on the rating process of credit raters in their global rating operations.

\subsection{Financial Performance of the Company}

The financial performance of the company matters a lot for the global corporate, but it shows a negative association with the ratings of the credit raters. It indicates that financial stability of the corporate sometimes is not regarded an important indicator for the global rating agencies. This variable determines if the financial performance of the 
company is improving and their management is agreeing to repay its debt to debtors and borrowers, how they would be rated by the credit rating agencies. Obviously, companies operating with stable financial performance would afford to repay its debt and they would enjoy more liquidity of their available resources than their competitors (Kisgen, 2009). This variable will determine how credit raters rate companies after evaluating their financial performance and their capability to repay its debt. Companies operating below their performance level often lack financial stability and they would be unable to repay their debt on time. But, companies with financial and economic stability would stand firmer to fulfill their financial and legal obligations of repaying their debt on time to the borrowing agencies (Diamond \& Rajan, 2009). The author analyzed the ongoing reputation of the crisis that CRAs faced in the extent of their role they played in rating Eurozone financial markets. Their credibility reduced because they didn't disclose risks timely and pushing financial markets and global financial systems on the verge of collapse. Politicians throughout the European countries showed their disagreement on negative role of the CRAs and demanded restrictions to be levied on the role and authority of CRAs about rating sovereign debt.

Corporate ability to repay debt: the researchers demanded that the regulations should be increased about credit raters to strengthen their corporate rating operations in determining the ability of corporate to repay its debt to the financial institutions. On the other hand, the credit raters in the United States are also not performing well and hiding them behind the First amendment (Crore et al., 2010). The legal argument regarding the ratings of CRAs is that they only issue opinions and they are not bind to give accurate and credible rating of corporate and financial markets.

Financial stability: Financial stability is important indicator which determines the rating of the credit raters and increased scrutiny of the credit raters in determining that no less or no reliance on credit raters would encourage more competition with less reliance on major credit raters rating the corporate at global level (Sufi, 2009).

Credibility and reliability: The European commission proposed that CRAs powers of sovereign debt rating should be suspended to veto their methodologies and to insist bail out talks under certain circumstances. Levine (2010) identified that credit rating agencies are still trying to make their reputation credible through recent actions. They received huge controversy in the sovereign debt crisis of the Eurozone and needed to improve their actions by predicting similar crisis in the future.

Hypothesis $\mathbf{H}_{5}$ : financial stability and creditability strongly influence on rating the credit raters in their global rating operations.

\subsection{Attitude of the Company to Repay Debt}

Though the attitude of the corporate towards the repayment of its debt is highly important to enhance the goodwill of the corporate, but it makes no influential role in determining the ratings of the credit raters offering their rating services in the global markets. Credit raters give no importance to the attitude of companies or their management to repay their debt while rating corporate in developing and developed countries meeting their rating processes and procedures. If the company has a positive attitude to repay its debt, their financial and economic credit rating should be improved and their credit trustworthiness also increases in comparison to other market players (Micu et al., 2004).

Corporate attitude in repayment of debt: the corporate attitude in repayment of their debt isimportant to the lending institutions, but it makes no considerable influence on the ratings of the credit raters in their global rating operations. If corporate show 
positive attitude in repayment of debt, their credibility among lenders and financial investors will be improved (Mathis et al., 2009).

Management role: in this study, the management role is not positively associated with the ratings of the credit raters though their positive attitude could play influential role in determining they are positively rated by the credit raters. Again, the management role is not always positive in repaying debt because they are more concerned with their recurring expenditures in their everyday business operations (O'Donovan, 2004). Therefore, it is not essential that ratings of the credit raters would be influenced due to positive management role.

Financial performance in repaying debt: the positive financial performance of the corporate is always important in determining their credit worthiness among lenders and creditors of the corporate (Ryan, 2012). But, company would face variations in their financial performance over the years due to changing market conditions and investor confidence on their business operations (Opp et al., 2013).

Hypothesis $\mathbf{H}_{6}$ : attitude towards repayment of debt and performance in repaying debt influences rating process of the credit raters in their global rating operations.

\subsection{Payment History of the Corporate}

On a legitimate level, though the payment history of the corporate is important but its role in influencing the ratings of the credit raters for globally operating corporations need to be studied. Studies have shows payment history is important for the corporations to make their good relationships with their investors, lenders and debtors, but it is not important for the ratings of the credit raters in their global rating operations (Matousek \& Stewart, 2009). Both nations have government-drove forms for qualifying appraisals offices. In any case, this DOES say something essential in regards to CRAs: "On a legitimate level, the FICO score framework today fills in as an administration authorized oligopoly" which implies that these offices exist fundamentally in light of the fact that legislatures REQUIRE them to exist (Cantor \& Packer, 1996).

Payment history: in the global business environment, payment history of the corporate is always important in determining their credibility among financial investors, lenders and creditors. Payment history may or may not influence the ratings of the credit raters because it could show variations as businesses grow outside their regional boundaries. In the current study, it is negatively associated with the ratings of the credit raters because it could make no influence on the rating processes of the credit raters (Haan \& Amtenbrink, 2011).

Financial procedures of corporate: the financial procedures of the corporate determine how serious they are in repaying debt in conducting their global business operations (Ferreira \& Gama, 2007). The financial procedures of the corporate vary from corporate to corporate and they need not be included as an important indicator to influence the ratings of the credit raters globally (Mathis et al., 2009).

Great implications of credit history: payment history of the corporate is always considered to be important in determining credit worthiness and getting positive opinions from the credit raters among other corporate operating in the same industry (Diamond \& Rajan, 2009). It would influence the ratings depending on the stability in the business operations of the corporate meeting their client needs in cross-cultural operations of the corporate among other businesses (White, 2010). 
Hypothesis $\mathbf{H}_{7}$ : payment history of the company in their global operations influence on rating the credit raters.

Outcomes of the Research

\subsubsection{Satisfaction of the Shareholders}

The research outcomes determine that ratings from the reliable credit ratings agencies affect the performance of the corporate to the commercial paper markets and their credibility among potential shareholders of the corporations operating in a specific industry (Almeida et al., 2014). The outcomes of the study clearly indicate that the credibility of the credit raters would be enhanced if their ratings are valid regarding the corporate. It would make enhance the satisfaction level of the shareholders of the corporate offering their services worldwide on the credibility and reliability of the credit rating agencies.

\subsubsection{Satisfaction of the Bondholders/Lenders}

The ratings of the credit raters could affect the access of a corporate to the bondholder and determine whether or not the institutional investors are allowed to invest into the securities of a corporate (Manso, 2011). If the ratings of the credit raters are valid and credible, the bondholders and lenders confidence of corporate will be increased and they will be confident in lending more and more money for the global operations on the corporate. The results of the study clearly indicate that the satisfaction and confidence of lenders is increased due to positivity of the credit raters in their rating processes. Therefore, credit raters should be highly focused on the accuracy of their ratings along with their considerable effects on the survival of the borrowers.

\subsubsection{Satisfaction of the Regulators}

The global credit raters give their forward looking opinions on the creditworthiness of the corporate and their ratings could make positive or negative impacts on the firm's performance. The creditworthiness determines the capability of the credit raters and their accurate ratings enhance the satisfaction of the regulating agencies worldwide in the financial sector (Shaheen \& Javid, 2014). The satisfaction of the regulators will also be improved as shown in the results below and the regulators will be more confident in regulating the rating agencies regarding their credible and authentic ratings of the best performing corporate worldwide and predicting negative impacts on their financial health in the future (Seetharaman et al., 2016). If the ratings of the credit raters are well regulated, it could increase the satisfaction of overall society by encouraging increased economic activities globally (Ekins \& Calabria, 2012, p. 2). Unlike satisfaction of the good rating practices of the credit raters, it would enhance the confidence and satisfaction of the overall society in which these credit raters operate and offering their ratings or opinions regarding the credit worthiness of the globally operating corporate (Elkhoury, 2008).

\section{RESEARCH OBJECTIVES}

\subsection{Research Methodology}

The research paper on evaluating the credit rating of credit raters uses primary data from conducting a survey while secondary data is collected from the literature review on the basis of which research was developed. Secondary data collection is derived from the literature review of 50 articles peer reviewed scholarly articles. 


\subsection{Data Collection}

An online survey is formulated by carefully preparing the questionnaire, distributing among selected respondents and collecting primary data. The survey questionnaire was based on pilot testing to be completed with selected credit rating agencies and their professionals and other industry experts. The industry experts participated in the process of data collection from several other industries that are getting credit rating from the credit raters and facing positive or negative issues regarding credit raters (Simshauser \& Ariyaratnam, 2014). The data is collected by conducting a survey questionnaire with some of the companies getting credit rating from the credit raters in the form of their feedback. The final questionnaire was prepared, modified and finalized considering the requirements of the selected respondents and the industry experts. In addition to preparing 3 questions for each of the seven variables of the study, the paper also included 3 questions to capture the demographic of the selected respondents. A 5 scale Likert scale method have been used for measuring the indicators.

\subsubsection{Demographic Characteristics of the Respondents}

A Likert scale is used to determine the strongest disagreement and strongest agreement among the selected respondents. The final survey questionnaire was sent to the selected 285 professionals to be located in different regions of the developed nations including the Middle East \& Africa, Asia Pacific, Europe and North \& South America. The usable responses were received from 146 professionals representing banking \& financial services, 62 professionals representing information technology and services, 25 professionals representing manufacturing services, 50 professionals representing software industry, 1 professional representing telecommunication and 1 professional representing consulting services. The following table gives the summary getting the demographic information of the respondents.

\section{DATA ANALYSIS}

Quantitative methods of data collection will be used in this research work. For analyzing the data, primary sources of data collection are used through Smart PLS method to determine the reliability of the data, convergent validity and discriminant validity of the data. It is considered to be an important tool that can be effectively used for structural equation modeling and producing reliable and trustworthy results. It is used to create an authentic framework by which hypothesis can be assessed and better results can be produced. Smart PLS software is employed specifically in this research work to determine the authenticity and reliability of the collected data of credit raters rating practices that they adopt for rating corporate in developing and developed countries. It employs composite modeling approach to test the hypothesis and the software is specifically selected because it is not associated with a normality condition of the data (Henseler et al., 2016). By using Smart PLS, the analysis is conducted to observe the rating of credit raters for their practices on corporate through structural modeling of reliability and validity measurements of data (Herring \& Kane, 2009).

Smart PLS modeling is used to determine the relevance significance of the relationships between two types of variables. It evaluates the structural modeling through path coefficients that could be interpreted considering their relationship with each other. Smart PLS is regarded as one of the prominent software that can be used to observe the results for the given set of data. 


\subsection{Reliability and Validity}

The Cronbach's Alpha scores are recorded to be more than 0.7 and indicate that the model selected is completely reliable for the given set of data which is collected through selected respondents and the literature collected from authentic published resources. By using the Smart PLS tool, the results observed for AVE should also be greater than 0.50 to indicate that the data observed is highly reliable. The results shown in the reliability validation indicates that AVE is $>0.50$ and we can say that the model is reliable with the satisfactory results.

The minimum AVE score is found 0.723506 which is above the minimum acceptable value. This proves that the convergent validity of the given set of data about the rating of credit raters is satisfactory.

\subsection{Structural Equation Model}

Path modeling is considered to be a special case of the structural equation model where single indicators of the variables are used in the casual model to determine their impact on rating the credit raters' dependent variable. The relationship between several independent variables and dependent variable of rating the credit raters are used in the equation format to sum the contribution of all paths through which these variables are interconnected with each other. The length of each can be successfully calculated in the form of path coefficients along with the path and the R-squared value of 0.998240 strongly supports the model to be used in this study.

\section{RESEARCH FINDINGS}

First hypothesis: $\mathrm{H}_{1}(\mathrm{t}$-value $=3.9623)$ and $(\beta=0.2555, \mathrm{p}<0.01)$ was supported i.e. conflict of interest has significant influence on rating the credit raters in their global operations of rating the corporate operating in world developed countries like the United States, UK and Asia Pacific countries. The leading rating agencies include the top 3 credit raters, the S\&P, Moody's and Finch and they conduct the operation of rating companies on the basis of their business and financial performance (Ellul et al., 2011). The role of security exchange commission and other bodies in regulating the ratings of credit raters and overcoming the conflict of interest would be highly important to improve their performance and reduce increasing worries of the world community in terms of their future financial predictions (Aras \& Crowther, 2008).

Second hypothesis: $\mathrm{H}_{2}(\mathrm{t}-\mathrm{value}=3.9623)$ and $(\beta=0.2555, \mathrm{p}<0.01)$ was supported i.e. debt level and credit score of the corporate has considerable influence on the rating of credit raters in their global operations of rating corporate. Earlier studies conducted by Bolton et al., (2009) observed the impacts of debt level of the companies on rating the credit raters, but the strength of their relationship has not been studied. Through the survey of this study, we have determined that debt level of the company in the global context is strongly associated with rating the credit raters in their credit rating process.

Third hypothesis: $\mathrm{H}_{3}$ ( $\mathrm{t}$-value $\left.=3.9623\right)$ and $(\beta=0.2555, \mathrm{p}<0.01)$ was supported i.e. length of credit history of the company has influencing role in rating of credit raters in their global operations of credit ratings. Che et al., (2014) observed that companies can develop a good credit history if they continue performing their business operations with patience. The credit history of the company is regarded as the major factor in determining that it would influence the credit score of a company (Besley \& Andrea, 2006). It is not something that companies can achieve overnight and always take time in building the credit history of the company. The paper evaluates that this variable would 
play an important role in determining the credit rating for a company. It evaluates whether CRAs give importance to the credit history of the company while assigning credit rating to the company. The age of the credit history is certainly important for a business and honestly CRAs should assign a good score if the credit history of the company is impressing (Benmelech \& Dlugosz, 2009).

Fourth hypothesis: $\mathrm{H}_{4}(\mathrm{t}$-value $=3.9623)$ and $(\beta=0.2555, \mathrm{p}<0.01)$ was supported i.e. attitude towards repayment of debt and performance in repaying debt influences rating process of the credit raters in their global rating operations. Different researchers have discussed on the demonstration of company's willingness to repay its debt including Poon \& Chan (2008) and Prodromos (2014), but the measure doesn't indicate magnitude that demonstration of company's willingness to repay its debt would impact on rating the credit raters for other studies conducted in the future to observe their relationship. The studies conducted in the context of specific country or region would also have different level of association.

Fifth hypothesis: $\mathrm{H}_{5}(\mathrm{t}-\mathrm{value}=3.9623)$ and $(\beta=0.2555, \mathrm{p}<0.01)$ was supported i.e. Financial stability and creditability strongly influence on rating the credit raters in their global rating operations.

Therefore, this hypothesis $\mathrm{H}_{5}$ of determining the association between financial performances of the company and rating process of the credit rating agencies, we conclude that by saying that financial performance of the company will always have a strong association with rating the credit rating agencies and it would make positive effect on rating the credit raters.

Sixth hypothesis: $\mathrm{H}_{6}(\mathrm{t}-\mathrm{value}=3.9623)$ and $(\beta=0.2555, \mathrm{p}<0.01)$ was supported i.e. Attitude towards repayment of debt and performance in repaying debt influences rating process of the credit raters in their global rating operations. Different studies have also been conducted on observing the implications of the length of credit rating agencies like Micu et al., (2004) who observed that if the company has a positive credit history, their financial and economic credit rating should be improved and their credit trustworthiness also increases in comparison to other market players.

Seventh hypothesis: $\mathrm{H}_{7}$ is used to measure the association between the payment history of the company and ratings of the credit raters for corporate operating in the developed regions like the US, UK and India. The value of $\mathrm{t}$-statistic for the sovereignty of credit is calculated to be 0.0335 which is lower than the significance, therefore, we reject $\mathrm{H}_{7}$ by saying that sovereignty of credit would have good implications on the everyday business operations of the corporate, but it could not make positive impact on rating the credit raters and rejected. The payment history of the company is considered to be most important indicator for determining the credit worthiness of the company operating globally and competing with other firms of the same industry. Poon (2003) observed that companies can achieve sovereignty of credit by buying large numbers of assets. If companies enjoy sovereign debt, investors' confidence would also be increased and credibility of the company among their potential buyers will also be increased. Company's ability or willingness to repay its debts can be determined through the solvency and asset liquidity of the company (Kenneth, 2015).

\subsection{Implications of the Research}

In the implications of the research, it is observed that only conflict of the interest is the single variable that could make influential role on the ratings of the credit raters. Other variables including the length of credit history, debt, demonstration of company's willingness to repay its debt, financial performance of the company to repay 
its debt, attitude of the corporate towards the repayment of debt and the payment history of the corporate makes no influential role on the ratings of the credit raters in their global rating operations. These variables could play an important role in the financial and business growth of the corporations, but it makes no considerable impact on the ratings of the credit rating agencies (Matousek \& Stewart, 2009).It also indicates that only the single variable 'conflict of interest' plays an important role for the credit raters in rating the companies. There should be no conflict of interest in order to achieve valid results from the credit raters about the performance and credibility of the credit rating agencies (Bozovic et al., 2011). The research shows that there should be a strong regulation for the credit rating agencies or credit raters to scrutinize their ratings and to make sure whatever they rate regarding the credit worthiness of different firms is credible and reliable (O'Donovan, 2004). The study also indicates that the managers and employees of the credit raters are well aware of several factors or variables that could impact their credibility and reliability though only conflict of interest is positively associated with the ratings of the credit rating agencies (Bolton et al., 2009). This relationship indicates that credit raters should only give importance to the conflict of interest as the major variable while other variables makes no influential role in making their rating decision (Das et al., 2007).

\subsection{Limitation and Scope for Future Research}

The research paper is only focused on evaluating the implications of seven selected variables on the rating of credit raters on the basis of previous literature and results collected from the selected respondents for this study. Out of the seven selected variables, only one variable 'the conflict of interest' could make strong positive impact on the ratings of the credit raters while the remaining variables makes no influence on their rating opinions regarding the credibility and reliability of the rating agencies (Herring \& Kane, 2009).

During the survey questionnaire, the observations are mentioned regarding the implications of these variables on the rating of credit raters. But the research has its limitations and needed support from cross functional teams, lacked statistical knowledge of using statistical tools and techniques for collecting and observing data and it might affect the rating process of the credit rating agencies across the developing countries (Micu et al., 2004). The research also gives a scope for the further research work on the basis of more variables to observe the authenticity and the creditworthiness of the credit raters rating the companies in developing countries. The research can also be carried out to find out how these variables would support in effectively implementing the well regulated rating process by the credit rating agencies (Hajek \& Michalak, 2013).

\section{DISCUSSIONS ANALYSIS AND CONTRIBUTIONS}

The study evaluates and analyzes seven specific variables on the basis of which credit rating agencies rate companies. It evaluates how much implications these variables could make on the rating process of credit raters to ensure authentic rating of the companies without getting any dissatisfaction from the companies rated by these credit raters in the developing countries (Jin et al., 2012).

The current research evaluates the credibility of credit raters in rating the companies from developing countries on the basis of selected variables. These variables determine how they rate different companies and whether they adopt similar criterion for rating the companies or use different criteria for companies operating in different countries (Altman \& Rijken, 2004). The variables about which survey questionnaires 
were prepared and distributed among selected respondents include conflict of interest, debt level of the companies being rated, credit history of a company on the basis of which it is rated, demonstration of the company's willingness to repay its debt, financial performance of the company in repaying the debt, attitude of companies for repaying the debt and the payment history of a company on the basis of which it is rated by credit raters (Roychoudhury \& Lawson, 2010). These variables are considered to be highly effective and useful in determining the credibility and reliability of the credit raters' ratings of the companies operating in the developing countries though only one variable is positively associated with the ratings of the credit raters. Most of the countries of the European Union believed that credit raters failed to properly disclose all the risks that erupted European countries and damaged their financial credibility very badly (Restrepo, 2013). The credit rating agencies hide behind the First Amendment which indicates that credit raters can never be held accountable for their ratings because these ratings are just based on their financial opinions. EU countries proposed investors to take a legal action against credit raters who negatively rate their performance despite their ability to repay debt and other variables are performing well (Poon \& Chan, 2008).

\subsection{Increased Scrutiny for Credit Raters}

Due to increased disagreement on the credit rating agencies ratings, the EU countries demanded cutting down their reliance on the ratings of these CRAs. They encourage more competition with more regulations of the credit raters including S\&P, Moody's and Fitch to reduce potential conflict of interest and to ensure they rate companies truly on the basis of their debt performance. The reforms package was proposed to take strict actions against the credit raters who rate companies without giving importance to the above mentioned variables of the study (Vassiliki \& Papalikonomou, 2010). To be reliable among world leading corporate, the credit raters must improve their quality of rating process by differentiating best performing corporate from under rated performers (Coval et al., 2009). The credit rating agencies including three major companies, the S\&P, Moody's and Fitch, should rate companies after carefully evaluating their financial performance of repaying their debt and the attitude of the companies to fulfill their commitment of repaying its debt without making any delays. These assessments of credit raters should be disclosed to the markets and their investors (Kenneth, 2015). The credit raters should be managed and supervised by new authorities of security commission regulations and government authorities to ensure their ratings are credible without any biases and discriminations. The credibility of credit rating agencies is considered to be highly important and it ensures their ratings are creditworthiness and reliable (Griffin \& Tang, 2012).

\subsection{Growing Importance of Credit Rating Processes of CRs}

The importance of credit raters have increased over the years to rate companies on the basis of their financial performance and their capability of repay their debts. They provide the creditworthiness and reliability of companies operating in different industries either operating in developing countries or developed nations (Bandyopadhray, 2006). They have become important financial market players and their importance has been admitted in the globalization of the capital markets, the markets of credit derivatives and their increased utilization in rating the companies. The credit raters work for effective risk management because they operate through multi-channel and multi-level regulatory frameworks that are legalized and self-regulated (Prodromos, 2014). The report evaluates that credit raters can impact both the suppliers and the 
buyers of the credit in terms of their credit rating processes (Varotto, 2011). The credibility and reliability of the results of credit raters would impact the overall performance of the financial markets throughout the globe (Orhan et al., 2015).

The role of credit raters have increased because they could make huge impact on the credit supply to the firms and credit supply to the nations in developing countries. It is essential that they should be held accountable for their actions of rating companies and countries on the basis of their financial performance and their willingness of repay their debts (Andrew, 2009). Credit rating agencies can also play an important role in the financial development and growth of companies because they provide invaluable information to the stakeholders of the companies and their investors (Amadei et al., 2011). The variables discussed in this study and their results collected from the selected respondents through survey questionnaire or through already published data on credit journal online indicate that CRAs give a direction to the investor and stakeholders about the current financial performance of a firm operating in a specific industry (Abid $\&$ Naifar, 2006). The leading credit raters would also receive revenues from those who issue securities and get better ratings from these agencies. The mandate of each ratings last for several years because the credit raters closely monitor the financial activities of the issuers. The credit raters can serve issuers by giving them an access to the financial markets where they can face cheaper costs of borrowing than the national level working traditional banks (Longstaff et al., 2005).

\section{CONCLUSIONS}

The current research identified how different variables can be used to determine the creditworthiness of the rating of credit raters. The research observed the ratings of the credit raters by exploring their impact on the ratings of the credit raters and found that only one variable 'the conflict of interest' could make positive influence on their rating processes. Other variables including debt, length of credit history, demonstration of company's willingness to repay its debt, financial performance of the company to repay its debt, attitude of the corporate towards the repayment of debt and the payment history of the corporate makes no influential role on the ratings of the credit raters in their global rating operations. In the global financial and operational sections of the corporations, these variables are considered to be important on the basis of which these companies are rated within their respective industries. The study identified some specific variables and explained whether credit raters (credit rating agencies) adopt all these measures for rating the corporate. It highlighted the loopholes in the credit rating processes of credit rating agencies that they have adopted for different corporate around the world (Boot et al., 2006). It also observed which organization is overseeing the processes of credit rating agencies and what norms they have adopted in verifying the authenticity of the credit raters. It explored on what basis these organizations or agencies evaluate the authenticity of the credit rating of the credit raters. According to the results collected in the current research, only the conflict of interest is positively associated with the ratings of the credit raters while other variables are negatively associated meeting their rating processes for the global corporations (Blume et al., 1998).

The paper discussed the credibility of the opinions of credit raters on the basis of some well selected variables including conflict of interest, debt level of corporate, length of credit history of the company, demonstration of company's willingness to repay its debt, financial performance of the company to repay debt, attitude towards the repayment of debt and past payment history of the company in repayment of debt 
(Bond et al., 2012). It highlighted how credit raters give weightage to these variables in making their opinions about corporate. Credit rating agencies have become an essential part of capital markets in the modern world. The paper examined the sovereignty of the assessment of credit raters on the basis of which they rate corporate around the globe (Bongaerts et al., 2012).

\section{REFERENCES}

Abid, F., \& Naifar, N. (2006). Credit-default swap rates and equity volatility: A nonlinear relationship. The Journal of Risk Finance, 7(4), 348-371.

Almeida, H., Cunha, I., Ferreira, M. A., \& Restrepo, F. (2017). The real effects of credit ratings: The sovereign ceiling channel. The Journal of Finance, 72(1), 249-290.

Altman, E. I., \& Rijken, H. A. (2004). How rating agencies achieve rating stability. Journal of Banking \& Finance, 28(11), 2679-2714.

Amadei, L., Di Rocco, S., Gentile, M., Grasso, R., \& Siciliano, G. (2011). Credit default swaps: Contract characteristics and interrelations with the bond market. Discussion Papers CONSOB.

Amato, J. D., \& Furfine, C. H. (2004). Are credit ratings procyclical? Journal of Banking \& Finance, 28(11), 2641-2677.

Andrew, W. L. (2009). Regulatory reform in the wake of the financial crisis of 20072008. Journal of Financial Economic Policy, 1(1), 4-43,

Andrews, C., \& Varrasi, E. (2015). Credit rating changes and post-M\& A firm value: Assessing the importance of credit ratings changes as a motive for successful M\&A (pp. 1-55). LUP Student Papers, Master's Programme in Corporate and Financial Management, Lund University School of Economics \& Management.

Aras, G., \& Crowther, D. (2008). Governance and sustainability: An investigation into the relationship between corporate governance and corporate sustainability. Management Decisions, 46(3), 433-448.

Ashcraft, A., Goldsmith-Pinkham, P., Hull, P., \& Vickery, J. (2011). Credit ratings and security prices in the subprime MBS market. American Economic Review, 101(3), 115-19.

Bandyopadhray, A. (2006). Predicting probability of default of Indian corporate bonds: Logistics and Z-score model approaches. The Journal of Risk Finance, 7(3), 255-272.

Becker, B., \& Milbourn, T. (2011). How did increased competition affect credit ratings? Journal of Financial Economics, 101(2011), 493-514.

Benmelech, E., \& Dlugosz, J. (2009). The alchemy of CDO credit ratings. Journal of Monetary Economics, 56(5), 617-634.

Besley, T., \& Prat, A. (2006). Handcuffs for the grabbing hand? The role of the media in political accountability. American Economic Review, 96(3), 720-736.

Biglaiser, G., \& Derouen, K. (2007). Sovereign bond ratings and neoliberalism in Latin America. International Studies Quarterly, 51(1), 121-138.

Blume, M. E., Lim, F., \& MacKinlay, A. C. (1998). The declining credit quality of US corporate debt: Myth or reality? The Journal of Finance, 53(4), 1389-1413.

Bolton, P., Freixas, X., \& Shapiro, J. (2009, February). The credit ratings game (pp. 1-45). NBER Working Paper No. 14712. Massachusetts Avenue, Cambridge: National Bureau of Economic Research.

Bond, P., Edmans, A., \& Goldstein, I. (2012, October). The real effects of financial markets. Annual Review Financial Economic, 4(1), 339-360. 
Bongaerts, D., Cremers, K. M., \& Goetzmann, W. N. (2012). Tiebreaker: Certification and multiple credit ratings. The Journal of Finance, 67(1), 113-152.

Boot, A. W., Milbourn, T. T., \& Schmeits, A. (2005). Credit ratings as coordination mechanisms. The Review of Financial Studies, 19(1), 81-118.

Božović, M., Urošević, B., \& Živković, B. (2011). Credit rating agencies and moral hazard. Panoeconomicus, 58(2), 219-227.

Cantor, R., \& Packer, F. (1996, October). Determinants and impact of sovereign credit ratings. Economic Policy Review, 2(2), 37-54.

Care, R., Trotta, A., \& Cavallaro, G. (2013, January). Exploring the relationship between CDS and rating announcements: A literature review and future research directions. International Journal of Economics \& Finance Studies, 5(1), 298-309.

Che, W. H., Han, H. Y., \& Hao, H. Y. (2014). Two-stage credit rating prediction using machine learning techniques. Kybernetes, 43(7), 1098-1113.

Chijoriga, M. M. (2011). Application of multiple discriminant analysis (MDA) as a credit scoring and risk assessment model. International Journal of Emerging Markets, 6(2), 132-147.

Croce, A., Lugo, S., \& Faff, R. W. (2011, April 21). Rating alignment, rating shopping and reputation of credit rating agencies: Evidence from the subprime crisis (pp. 1-27). Working Paper. SSRN Electronic Journal.

Das, S. R., Duffie, D., Kapadia, N., \& Saita, L. (2007). Common failings: How corporate defaults are correlated. The Journal of Finance, 62(1), 93-117.

Diamond, D. W., \& Rajan, R. G. (2009). The credit crisis: Conjectures about causes and remedies. American Economic Review, 99(2), 606-10.

Dimson, E. (1979). Risk measurement when shares are subject to infrequent trading. Journal of Financial Economics, 7(2), 197-226.

Ekins, E. M., \& Calabria, M. A. (2012). Regulation, market structure, and role of the credit rating agencies. Policy Analysis No. 704.

Elkhoury, M. (2008). Credit rating agencies and their potential impact on developing countries. United Nations Conference on Trade and Development

Ellul, A., Jotikasthira, C., \& Lundblad, C. T. (2011). Regulatory pressure and fire sales in the corporate bond market. Journal of Financial Economics, 101(3), 596-620.

Fahrmeir, L., Heumann, C., Künstler, R., Pigeot, I., \& Tutz, G. (2016). Statistik: Der weg zur datenanalyse. Springer-Verlag.

Fama, E. F., \& French, K. R. (1989). Business conditions and expected returns on stocks and bonds. Journal of Financial Economics, 25(1), 23-49.

Fatemi, A., \& Fooladi, I. (2006). Credit risk management: A survey of practices. Managerial Finance, 32(3), 227-233.

Ferreira, M. A., \& Gama, P. M. (2007). Does sovereign debt ratings news spill over to international stock markets? Journal of Banking \& Finance, 31(2007), 3162-3182.

Focardi, S. M., \& Fabozzi, F. J. (2005). An autoregressive conditional duration model of credit-risk contagion. The Journal of Risk Finance, 6(3), 208-225.

Goddard, J., Molyneux, P., \& Wilson, J. O. S. (2009). The financial crisis in Europe: Evolution, policy response and lessons for the future. Journal of Financial Regulation \& Compliance, 17(4), 362-380.

Goh, J. C., \& Ederington, L. H. (1993). Is a bond rating downgrade bad news, good news, or no news for stockholders. Journal of Finance 48(2), 2001-2008.

Graham, J. R., \& Harvey, C. R. (2001). The theory and practice of corporate finance: Evidence from the field. Journal of Financial Economics, 60(1), 187-243. 
Griffin, J. M., \& Tang, D. Y. (2012). Did subjectivity play a role in CDO credit ratings? Journal of Finance, 67(3), 1293-1328.

Guimon, J. (2005). Intellectual capital reporting and credit risk analysis. Journal of Intellectual Capital, 6(1), 28-42.

Haan, J. de \& Amtenbrink, F. (2011, January). Credit Rating Agencies (pp. 1-37). De Nederlandsche Bank Working Paper No. 278. Amsterdam, Netherlands.

Hajek, P., \& Michalak, K. (2013, October). Feature selection in corporate credit rating prediction. Knowledge-based Systems, 51, 72-84.

Hand, J. R. M., Holthausen, R. W., \& Leftwich, R. W. (1992, June). The effect of bond rating agency announcements on bond and stock prices. The Journal of Finance, 47(2), 733-752.

He, J., Qian, J. Q., \& Strahan, P. (2012, December). Are ratings all created equal? The impact of issuer size on the pricing of mortgage-backed securities. Journal of Finance, 67(6), 2097-2137.

Henseler, J., Hubona, G., \& Ash Ray, P. (2016). Using PLS path modeling in new technology research: Updated Guidelines. Industrial Management \& Data Systems, 116(1), 2-20.

Herring, R. J., \& Kane, E. J. (2009). Financial economists roundtable statement on reforming the role of the rating "agencies" in the speculation process. Journal of Applied Corporate Finance, 21(1), 28-33.

Hunt, J. P. (2008, September). Credit rating agencies and the 'worldwide credit crisis': The limits of reputation, the insufficiency of reform, and a proposal for improvement. Columbia Business Law Review, 109(1), 1-74.

Jais, K. M., Nawawi, A., \& Salin, A. S. A. P. (2016). Reduction of audit quality by auditors of small and medium size audit firms in Malaysia: A case of premature sign-off of audit documents. Journal Accounting Business \& ManagementInternational, 23(2), 1-12.

Jin, J., Yu, Z., \& Mi, C. (2012). Commercial bank credit risk management based on grey incidence analysis. Grey Systems: Theory \& Application, 2(3), 385-394.

Kenneth, A. (2015). Risk-based regulation: The future of Nigerian banking industry. International Journal of Law \& Management, 57(3), 201-216

Kisgen, D. J. (2009). Do firms target credit ratings or leverage levels? Journal of Financial \& Quantitative Analysis, 44(1), 1323-1344.

Kisgen, D. J., \& Strahan, P. E. (2010). Do regulations based on credit ratings affect a firm's cost of capital? Review of Financial Studies, 23(2), 4324-4347.

Kreps, D. M., Milgrom, P., Roberts, J., \& Wilson, R. (1982). Rational cooperation in the finitely repeated prisoners' dilemma. Journal of Economic Theory, 27(1), 245-252.

Levine, R. (2010). An autopsy of the US financial system: Accident, suicide, or negligent homicide. Journal of Financial Economic Policy, 2(3), 196-213.

Liu, L. G., \& Ferri, G. (2001). How do global credit rating agencies rate firms from developing countries? (pp. 1-35). ADB Institute Research Paper Series No. 26.

Longstaff, F. A., Mithal, S., \& Neis, E. (2005). Corporate yields spreads: Default risk or liquidity? New evidence from the credit default swaps market. Journal of Finance 60, 2213-2253.

Louberge, H., \& Schlesinger, H. (2005). Coping with credit risk. The Journal of Risk Finance, 6(2), 118-134.

Manso, G. (2011). Feedback effects of credit ratings. Journal of Financial Economics, 109(3), 535-548. 
Mathis, J., McAndrews, J., \& Rochet, J. C. (2009). Rating the raters: are reputation concerns powerful enough to discipline rating agencies? Journal of Monetary Economics, 56(5), 657-674.

Matousek, R., \& Stewart, C. (2009). A note on ratings of international banks. Journal of Financial Regulation \& Compliance, 17(2), 146-155.

McAndrews, M., \& Rochet, J. C. (2009). Rating the raters: Are reputation concerns powerful enough to discipline rating agencies. Journal of Monetary Economics, 56(5), 657-674.

Memon, A. H., \& Rahman, I. A. (2014). SEM-PLS analysis of inhibiting factors of cost performance for large construction projects in Malaysia: perspective of clients and consultants. The Scientific World Journal, 1, 1-9.

Micu, M., Remolona, E. M., \& Wooldridge, P. D. (2004, June). The price impact of rating announcements: Evidence from the credit default swap market. BIS Quarterly Review, 2, 55-65.

O’Donovan, M. (2004). The nature of risk: Credit agencies and light regulation-building a market code. Balance Sheet, 12(5), 38-41.

Opp, C. C., Opp, M. M., \& Harris, M. (2013). Rating agencies in the face of regulation. Journal of Financial Economics, 108(1), 46-61.

Orhan, M., Saka, H., \& Yuksel, H. (2015). Ethical and systemic dilemmas of credit ratings. Turkish entrepreneurship and business ethics association. Turkish Journal of Business Ethics, 8(1), 93-108.

Poon, W. P. H. (2003). Are unsolicited credit ratings biased downward? Journal of Banking \& Finance, 27(1), 593-614.

Poon, W. P. H., \& Chan, K. C. (2008). An empirical examination of the informational content of credit ratings in China. Journal of Business Research, 61(2008), 790-797.

Prodromos, V. (2014). Greek fiscal crisis and repercussions for the property market. Journal of Property Investment \&o Finance, 32(1), 21-34.

Restrepo, F. (2013, October 30). Credit ratings and the cost of debt: The sovereign ceiling channel (pp. 1-52). Working papers. Carroll School of Management Boston College.

Roychoudhury, S., \& Lawson, R. A. (2010). Economic freedom and sovereign credit rating and default risk. Journal of Financial Economic Policy, 2(2), 149-162.

Ryan, J. (2012). The negative impact of credit rating agencies and proposals for better regulation. Working Paper FG 1, SWP Berlin.

Seetharaman, A., Patwa, N., Jadhav, V., \& Saravanan, A. S. (2016). Accounting and financial systems and tools for effective leadership and management. Journal Accounting Business \& Management-International, 23(2), 45-60.

Shaheen, R., \& Javid, A. Y. (2014). Effect of credit rating on firm performance and stock return: Evidence from KSE listed firms. PIDE Working Papers No. 104. Pakistan Institute of Development Economics.

Simshauser, P., \& Ariyaratnam, J. (2014). What is normal profit for power generation? Journal of Financial Economic Policy, 6(2), 152-178.

Skaife, H. A., Collins, D. W., \& LaFond, R. (2004). The effects of corporate governance on firms' credit ratings. SSRN Electronic Journal, 42(1-2), 203-243.

Skreta, V., \& Veldkamp, L. (2009). Ratings shopping and asset complexity: A theory of ratings inflation. Journal of Monetary Economics 56(2), 678-695.

Sufi, A. (2009). The real effects of debt certification: Evidence from the introduction of bank loan ratings. Review of Financial Studies, 22(4), 1659-1691.

Turvey, C. G., Bogan, V. L., \& Yu, C. (2012). Small businesses and risk contingent credit. The Journal of Risk Finance, 13(5), 491-506. 
Varotto, S. (2011). Liquidity risk, credit risk, market risk and bank capital. International Journal of Management Finance, 7(2), 134-152.

Vassiliki, L., \& Papalikonomou (2010). Credit rating agencies and global financial crisis: Need for a paradigm shift in financial market regulation. Studies in Economics \& Finance, 27(2), 161-174.

White, L. J. (2010). Markets: The credit rating agencies. The Journal of Economic Perspectives, 24(2), 211-226. 